\title{
"-isms" and psychiatry: the threat of single issue politics
}

\author{
Bruce G. Charlton, Anatomy Department, Glasgow University, Glasgow G12 8QQ, \\ Scotland
}

Single issue political movements (such as feminism, anti-racism, Marxism, homosexual liberation, animal rights etc) have been a major characteristic of the post-1960s radical scene in the United States and Western Europe. While such movements typically start out doing a good job, it is my assertion that they have now reached the point of posing a serious threat to medicine at large, and to psychiatry in particular.

I will take feminism as my example to stand for a whole range of pressure groups, as feminism seems to be making the largest impact on British psychiatry. However, the arguments apply mutatis mutandis to other "-isms".

When feminism started out in the 19th century there was not much doubt that it was almost wholly "a good thing". Like other single issue-ists, feminists focused upon the plight of a group of people which they defined as "oppressed" (although not in this case an oppressed "minority"). They used a multitude of media-newspapers, magazines, books and TV, schools and universities, public demonstrations and private conversations - to advance their cause. And so they proceeded to raise the public level of awareness of women and their particular problems, needs and rights. You would now be hard pressed to find anybody of a liberal, educated cast of mind (any psychiatrist, for example) who would seriously assert that women should be paid less for the same job, or that women are intrinsically less able, should be second-class citizens or whatever. In this sense we are all feminists now.

However, disadvantages began to emerge when the single issue of gender was extended from criticising an obvious abuse to dominating the whole of human endeavour - feminism became a way of life. We now see people who have defined themselves, first and foremost, as "feminists": they regard feminism as the single moral and political dimension of importance: gender "issues" come first, and everything else (including science, medicine and psychiatry) comes after.

At root, professional feminists interpret the human world in one dimension - the infinitude of social reality is strung out along an axis between sexism and feminist enlightenment. The problems of women are seen as so urgent and compelling that they are the only real source and focus for thought and action. The feminist who takes an interest in psychiatry, who approaches a clinical or research situation, has already decided that women's psychiatric problems are more worthy of attention than men's. The key division by gender has been made before entering the worlds of medicine or science these disciplines are enlisted only to confirm that which has already been decided.

It is as if a physician was concerned only with the single dimension of blood pressure, and ignored the multitude of other medical illnesses. A physician whose concern for the well-being of the patient was overwhelmed by a monomaniacal desire to correct hypertension would be a disaster. Of course, such a physician could not help but do some good-a proportion of patients indeed suffer from high blood pressure, as sexism is indeed sometimes a major problem - but if the attitude is misguided and unbalanced, it results in fantastically misplaced emphasis and inappropriate efforts.

Psychiatry is particularly vulnerable to the lure of "-isms" for two reasons. The first is that the speciality is attractive to those of a generally radical and "right-on" persuasion, and sexism-hunting is one part of the "political correctness" power game. But more importantly, the patients are seen as more firmly a part of their social situation in psychiatry than is the case for many other branches of medicine. If the psychiatrist has a simplistic or overvalued social philosophy, it is likely to wreak greater damage here than it would do in surgery or anaesthetics.

Ethical and clinical distortions are the inevitable result of systematically privileging one half of the human race. Issues of absolute generality-such as actual definitions of health, the provision and distribution of health services, poverty and wealth, reproduction, doctor patient relationships, the pressures and duration of professional training etc etc-all are obscured and made more difficult of solution by considering women as a priority and in isolation. A double-bind is applied whereby any difference between men and women is interpreted as a consequence of oppression - and given the infinite number of measurable parameters, differences are inevitable. Greater incidence of neurotic mental illness in women is seen as following on from lifelong persecution. But a longer female life expectancy is not interpreted as evidence of having a better life 
than males-if anything it produces another "women's problem" of being old, frail and single.

Whether or not feminism counts as a good thing therefore depends upon the relative need of the oppressed group, whether money and effort might be better spent, and what are the consequences to society at large. The work of the donkey sanctuary is in itself a decent enough activity, but the fact that it is the fifth largest animal charity must strike most people as a bit over the top-the needs of a few thousand donkeys just don't justify that level of concern in the wider scheme of things. I suggest that the same argument applies to the setting-up of "counselling" services at "well-woman" clinics.

Feminism is invading psychiatry, as witness the level of media coverage and the flurry of scholarly activity, for example the British Journal of Psychiatry's recent supplement Women and Mental Health. This booklet betrays some of the most entrenched "heads I win, tails you lose" style of reasoning. It is, of course, perfectly legitimate to do research concentrating on gender differences; but only when this is embedded within a broader picture of the well-being of all patients.

We must not be inhibited by "liberal guilt" from expressing our incredulity when the feminist perspective oversteps the mark. Feminists are not the "spokespersons" for womankind; many of them are as self-interested and career-minded as any other professional group. There are comfortable niches in education, the media, publishing and health care for the single-issue-ists of all hues. Ultimately, of course, the different brands of pressure group politics are mutually incompatible, but at present there is an unspoken truce between them, and they never attack each other, instead concentrating their efforts against the "privileged"-especially those who are white, male, heterosexual, middle class, educated and reasonably well-off.

To summarise, I believe that any single issue politics will ultimately lead to harm no matter what its good intentions - any virtue pursued to excess becomes a vice. In the final analysis "-isms" are merely self-righteous, adolescent faddism writ large. On mature judgement, we come to realise that in psychiatry, as in life, there are many and conflicting goals to be balanced, and fanaticism just will not do.

There is a danger that the guiding mission of psychiatry - to help people with mental illnessbecomes damaged by their prior division according to gender or sexual preference, or by race, by socioeconomic class, academic attainment or whatever it might be. The goal of psychiatry is purely to consider the best interests of the patient as a patient, and not as a representative of some group - "oppressed" or otherwise. Such aspects should be taken into consideration only to the extent which is helpful to the management of their illness. Beyond that is not the concern of the psychiatrist qua psychiatrist. "-Isms" must take second place to good scientific and clinical practice.

\begin{abstract}
"he received his knighthood entirely in connection with the work he undertook in regard to the origin of the Volunteer movement, and not for his valuable services which he had rendered to the insane". (Dr D. Hack Tuke commenting on Dr J. Bucknill's knighthood, 1894).
\end{abstract}

"Like his game of golf, Dr Worth drove a long and straight ball through the fairway of the secretarial work which he had to perform, and if he occasionally found his way into a bunker by bad luck, or perhaps in his case by over-driving, one found he was as useful with his niblick as with his driver, as he got out of his difficulties". (Professor G. M. Robertson on Dr R. Worth, Secretary, 1925). 